Original Research

\title{
Partner Relationship Management Architecture Design For SME During Pandemic Era
}

\author{
Dhiani Tresna Absari ${ }^{1}$, Daniel Soesanto ${ }^{1^{*}}$ \\ ${ }^{1}$ Informatics Engineering, Faculty of Engineering, University of Surabaya, Surabaya-Indonesia \\ * corresponding author: daniel.soesanto@staff.ubaya.ac.id
}

\begin{abstract}
The pandemic situation encourages every business, including small and medium scale, to transform towards an online business. This is done to be able to continue to reach customers and carry out existing business processes well. However, with the reduction or disappearance of face-to-face meetings, the quality of the relationship decreases both on the customer and business partner side. This research focuses on the relationship with business partners, where the exchange of information and data is not optimal in this section, and even errors can occur. Many studies have tried to optimize relationship management with business partners, but none have focused on small and medium-sized businesses during this pandemic. SME's need to manage their business relationships. However, according to research that has been done, many of these business models do not realize the importance of this, and only focus on selling.. This research aims to design PRM architecture designs for small and medium-scale enterprises in this pandemic era. This research resulted in an e-marketplace design that implements PRM for SMEs by applying a recommendation system for distributors to provide the right product to each reseller. Through the results of initial trials conducted by users, both from distributors and resellers, it is easier to understand each other's needs with this e-marketplace.
\end{abstract}

Keywords: SMEs, PRM, channel management, recommendation system, pandemic

\begin{abstract}
Abstrak-Situasi pandemi mendorong setiap bisnis, termasuk skala kecil dan menengah, untuk bertransformasi menuju bisnis online. Hal ini dilakukan untuk dapat terus menjangkau pelanggan dan menjalankan proses bisnis yang ada dengan baik. Namun, dengan berkurangnya atau hilangnya pertemuan tatap muka, kualitas hubungan menurun baik di sisi pelanggan maupun mitra bisnis. Penelitian ini berfokus pada hubungan dengan mitra bisnis, dimana pertukaran informasi dan data tidak optimal pada bagian ini, bahkan kesalahan dapat terjadi. Banyak penelitian telah mencoba mengoptimalkan manajemen hubungan dengan mitra bisnis, tetapi tidak ada yang fokus pada usaha kecil dan menengah selama pandemi ini. Padahal sebenarnya SME pun sangat perlu mengelola relasi bisnisnya. Namun menurut riset yang pernah dilakukan, bisnis model ini banyak yang belum menyadari pentingnya hal tersebut, dan hanya fokus pada menjual. Penelitian ini bertujuan untuk merancang desain arsitektur PRM untuk usaha kecil dan menengah di era pandemi ini. Penelitian ini menghasilkan desain e-marketplace yang mengimplementasikan PRM untuk UKM dengan menerapkan sistem rekomendasi bagi distributor untuk menyediakan produk yang tepat untuk setiap reseller. Melalui hasil uji coba awal yang dilakukan oleh pengguna, baik dari pihak distributor maupun reseller menjadi dimudahkan untuk lebih saling memahami kebutuhan masing-masing dengan adanya e-marketplace ini.
\end{abstract}

Kata kunci: SMEs, PRM, channel management, sistem rekomendasi, pandemi

\section{INTRODUCTION}

The pandemic is still happening, causing businesses from various fields to feel the impact. This is what drives every business to turn into an online business (Barnes, 2020)(Fernandes, 2020)(Griffin and Denholm, 2020). Multiple kinds of platforms are used to support the running of this online business, ranging from interactive communication facilities to marketplaces, both free and paid (Gerwe, 2021). All business processes within the company are forced to switch online, from product introduction, product sales, after-sales service to managing customer relationships. But what is often forgotten is that businesses cannot stand alone and sell their products. Businesses need relationships with customers and the entire business network that can support the running of the business properly. Of course, during a pandemic where people cannot freely meet and gather with each other, it becomes a challenge in itself to establish a good business network relationship.

Various problems began to arise in business networks during this pandemic, ranging from data and information errors obtained by business partners to differences in assumptions about existing data, potentially leading to mistakes in business decision-making (Bermes, 2021). These things can then also impact the less than optimal distribution of goods from one business actor to another in the network. This can potentially damage the good relations between business partners in the network at a more severe level.

Relationships in a business have been the main focus for a long time. This can be seen from the development of the concept of customer relationship management. In this concept, 
Dhiani, T.A., et al., Partner Relationship Management Architecture Design For SME During Pandemic Era, KELUWIH: Jurnal Sains dan Teknologi, Vol.2(2), 96-102, Agustus 2021.

https://doi.org/10.24123/saintek.v2i2.4567

the company or business will try to understand customer desires to increase customer satisfaction (Oliver Richard L., 1980). This customer satisfaction will later impact the decision to make a repeat purchase or be referred to as a repeat order without coercion. In the long term, it is expected to increase customer retention in the business that runs it. (Vos et al., 2021). However, trying to understand customer desires is not an easy thing to do, considering that to achieve this, companies need to capture a lot of customer data and then process it to get information about these customers. This information will then be translated into customer desires. Therefore, the Customer Relationship Management Information System was introduced, wherein a computer-based system will assist this concept of data collection and data processing. Through a computer-based system, of course, this will be easier to do, given the computational capabilities of machines which are higher than humans at the level of resilience.

However, in a business, relationship, not only towards customers but also with existing business partners. Customers are not the only parties who need to be understood. There are still business partners who also need to understand their desires so that business processes from upstream to downstream can run well (Agarwal, Singh and Agariya, 2017). Business partners can be in the form of producers, suppliers, distributors, to small resellers. The last part that is often forgotten to handle is resellers, especially in businesses that are not too big like SMEs. Even though this reseller is one of the keys to the success of an online business (Li et al., 2021), especially during this pandemic. This is because resellers are one way to expand the online business network for small business scales such as SMEs (Nayati Utami et al., 2019). While on the other hand, according to research that has been done, many business models do not realize the importance of this, and only focus on selling (Stokes and Lomax, 2002).

Partner relationships are often referred to as channel relationships, wherein these concept arrangements are made for the relationship between one business party and other parties in the business network to bring benefits to all of these parties. (Agariya and Singh, 2011). In the research conducted by Agarwal and Singh, this relationship arrangement is also intended to obtain a win-win solution for all parties involved (Agarwal and Singh, 2014). In terms of the platform, it was found that the implementation of Partner Relationship Management (PRM) on a website basis can have a better impact because of the ease of access and integration (Kedah et al., no date). In addition, PRM can also increase the trust of every business party involved in it (Storey and Kocabasoglu-Hillmer, 2013), where this is also the impact of significantly improving the quality of relations between parties (Barac et al., 2017)(Fedotova, Shynkarenko and Kryvoruchko, 2018). However, the ultimate goal of PRM remains to increase profits for the company, which begins with increasing customer satisfaction from the company (Agarwal, Singh and Agariya, 2017).

In another study, it was also found that good relations with business partners can increase the company's ability to innovate the products or services produced (Ernawati and Hamid, 2021). From a security perspective, good relationship management with partners also increases transparency in the relationship itself, which can increase trust in the relationship, as previously mentioned. (Gruenberg et al., 2006). This transparency can also minimize conflicts that usually occur between resellers and suppliers (Sa Vinhas and Gibbs, 2012)(Tsay and Agrawal, 2004)(Leverin and Liljander, 2004). However, it should also be remembered that intimate relationships with resellers also can harm brand value if the reseller does not have a high commitment to maintaining the brand value. (Gupta, Väätänen and Khaneja, 2016).

In supply chain management, many parties are involved, so in this context, PRM can be implemented. In a study conducted by Wu et al. (2011), one of the things that can be done to improve the performance of PRM in SCM is to do information sharing (Wu et al., 2011). Therefore, this research will aim to develop the architectural design of partner relationship management for SMEs during this pandemic. The novelty of this research lies in the implementation of PRM in SMEs during the pandemic. 


\section{METHOD}

Design Science Research (DSR) is a variance of the Information Systems research methodologies which will be applied in this research. This method was chosen because, through this method at the same time, new knowledge can be generated that is in line with the product being created (vom Brocke, Hevner, and Maedche, 2020). The knowledge that is expected to be obtained is about the factors that must be considered when creating PRM for SMEs. Iteratively, the creation, evaluation, and improvement process is carried out in DSR (Lim, Baba and lijima, 2019). The DSR method consists of several stages, namely: problem identification, goal solution definition, solution design and development, demonstration and evaluation, and communication.

1. Phase Identification of Problems and Definition of Solution Objectives

Building fundamental knowledge of the system to be developed needs to be done as a preceding step to the problem identification stage. Therefore, observations and interviews are carried out to get an understanding of the current transaction system between distributors and resellers so that problems can be identified. In addition, literature studies from various related references/journals were carried out to obtain information to support the development of the expected conditions as a solution.

2. Solution Design and Development Stage

Based on the problems that have been discussed in the previous step, this stage is carried out to develop a system design that can help process transactions between distributors and resellers online. The designs developed include database design, process design, and user interface design.

3. Demonstration and Evaluation Stage

Alpha testing and beta testing are performed as tools in the demonstration and evaluation stage. The system that has been developed first is then demonstrated and evaluated by the developer and certain clients as distributors and resellers in limited. Demonstration and evaluation are then performed to more clients as an emarketplace system.

4. Communication

The results of the demonstration and evaluation are then communicated to academics to get feedback to revise the developed system. In this section, revisions will continue to be made on the developed system to obtain the most relevant results with the feedback received.

\section{RESULT AND DISCUSSION}

Various information and problems can be identified after deep observations, interviews, and benchmarks are performed on various similar systems. From the results of observations and interviews of transaction management at distributors in general and in particular, to the two distributors, Jims Honey and Raja Boneka have found that transaction communication is currently used on social media. Product information is broadcast through social media groups without considering the shopping preferences of the reseller. Likewise, product orders are also attained using social media. No stock information was shared, so the reseller may not get a certain amount of the product as expected. Benchmark results against existing application-based distributor transaction systems generally have a weakness in the product search feature which is unable to properly filter reseller needs based on their order history, rating, or preferences. As with previous research on personal recommendation systems (Sari and Sary, 2017), this recommendation system has been proven to significantly increase loyalty and sales. It can encourage customers to buy products that match their preferences or can be used for cross-selling by offering products related to their preferred product. And the last result of observation obtained that the drop ship system, in general, cannot be accomplished by most of the systems analyzed.

As a solution design and development stage, this research is to design and develop an e-marketplace system that has purchasing features between distributors and resellers where resellers can buy products from any distributors who join the e-marketplace directly through 
the system. Resellers can also see the stock availability of each distributor so they can adjust the number of items to purchase. In this application, resellers can also directly send purchased products to their customers with a dropship system. In addition, the system was developed with a recommendation system feature based on the reseller's purchase history and the rating given by all resellers. This feature may help resellers to obtain information on new products that are matched to their shopping preferences. The recommendation feature was developed using the Slope One algorithm. The slope one algorithm is one of the algorithms used to create a recommendation system (Jiang and Lu, 2013) which is calculated based on ratings and popularity. The recommendation feature in the developed system is based on the reseller's transaction history by considering product ratings. The following Figure 1. Home Display Process. shows the design process in relation to the recommendation system.

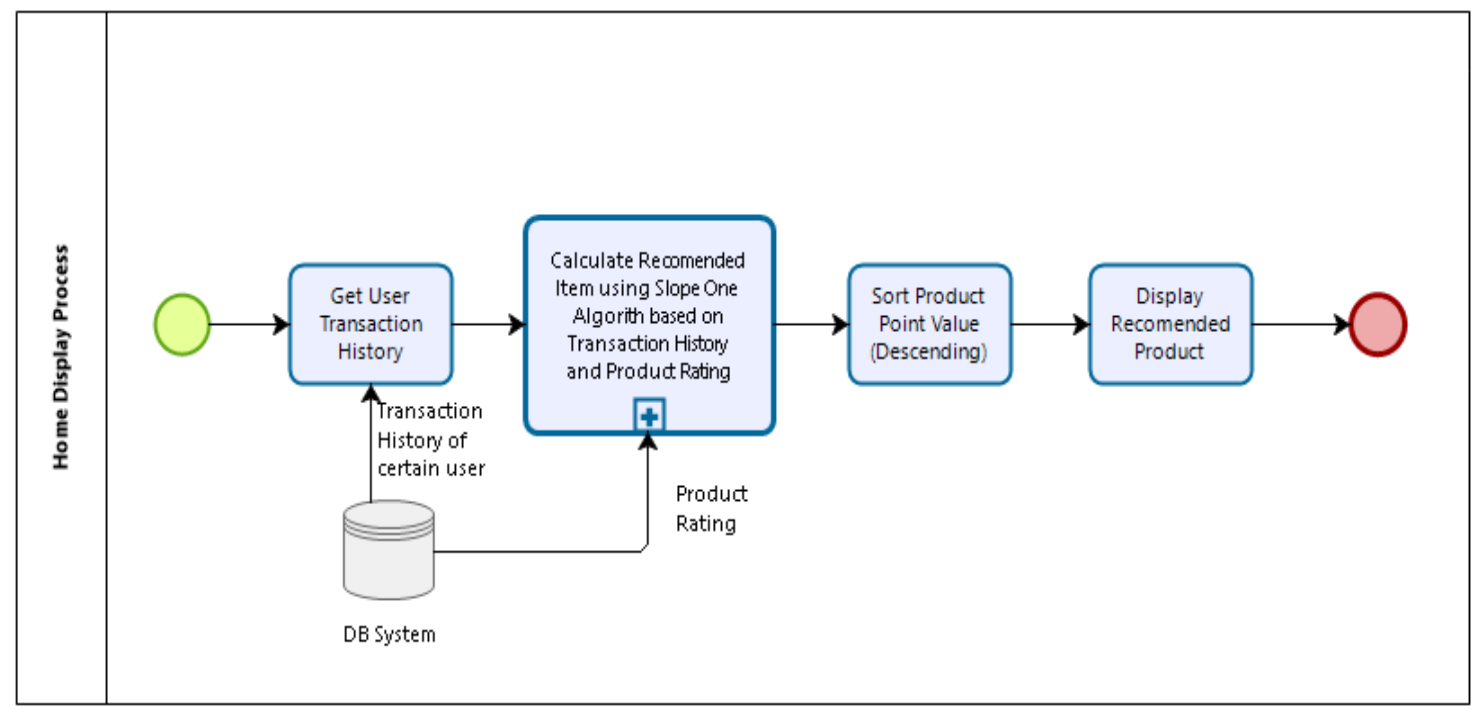

Figure 1. Home display process.

The product recommendation page can be seen on the home page right after the user's login. Some specified products are recommended for each reseller on the product recommendation page, depending on their transaction history and product rating. The products displayed are those products that have a high rating prediction for a particular reseller. If the reseller is interested in the product, the reseller can click on the product photo and be redirected to the product detail page, as shown in Figure 2 . Homepage.

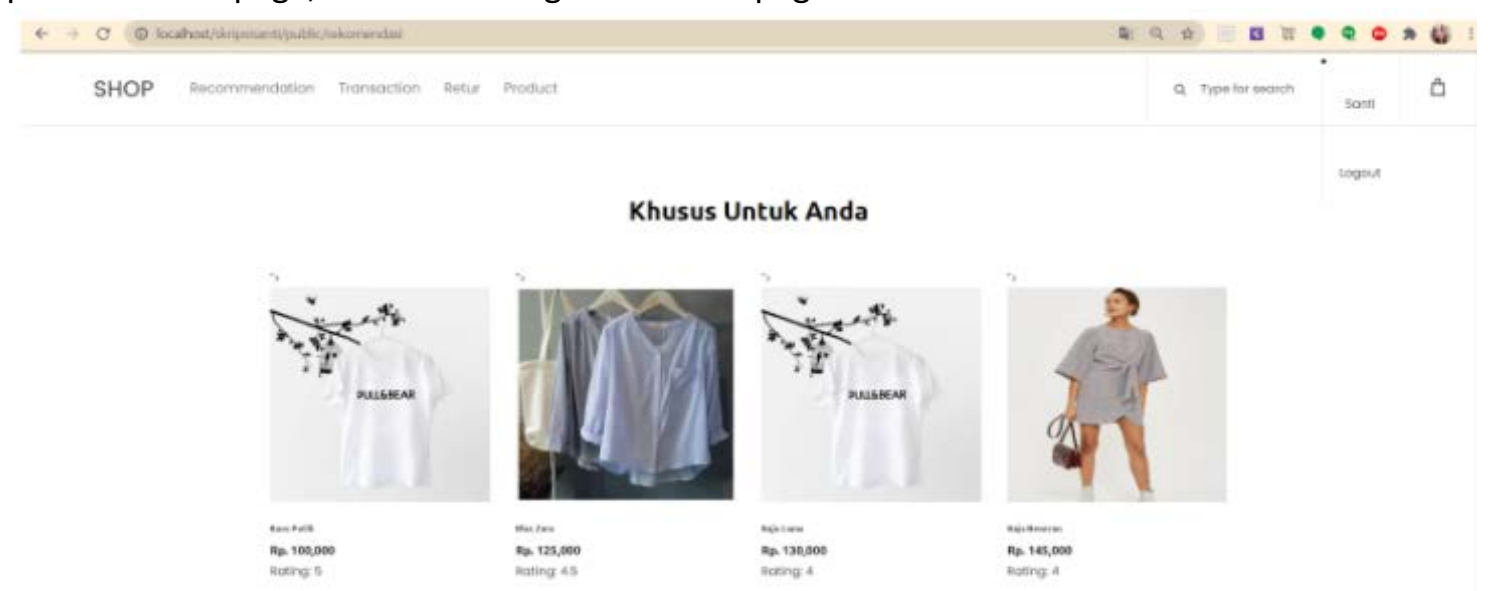

Figure 2. Homepage.

System validation ensures that the development of a partnership relationship management information system for online distributors and resellers had aligned with the user needs. 
Dhiani, T.A., et al., Partner Relationship Management Architecture Design For SME During Pandemic Era, KELUWIH: Jurnal Sains dan Teknologi, Vol.2(2), 96-102, Agustus 2021.

https://doi.org/10.24123/saintek.v2i2.4567

Therefore, the structure of the prepared questionnaire follows the results of the identification of the needs that have been done previously. The video recording of the developed system has been demonstrated to the targeted users and evaluated by a questionnaire. The distribution of the questionnaire was divided into two parts, the first being distributed to 15 resellers and the second being distributing questionnaires to 3 distributors. The selected resellers and distributors are those located in Surabaya and have a small to medium business scale. The sampling method used to find respondents is to use simple random sampling. The questionnaire results show that the user is helped by the main features provided by the system, as shown in Table 1. The measurement of respondent validation uses a Likert scale with five measurement scales, but because all respondents' answers are only spread over the top three scales, table 1 only shows the top three scales of the Likert scale.

Table 1

Test Results

\begin{tabular}{|c|c|c|c|}
\hline Resellers & $\begin{array}{l}\text { Strongly } \\
\text { Agree (\%) }\end{array}$ & $\begin{array}{l}\text { Agree } \\
(\%)\end{array}$ & $\begin{array}{l}\text { Neutr } \\
\text { al (\%) }\end{array}$ \\
\hline The system helps resellers to see a list of products sold. & 60 & 40 & \\
\hline The system helps resellers to see product detail & 40 & 53,3 & 6,7 \\
\hline $\begin{array}{l}\text { The system helps resellers to see the stock and price of the } \\
\text { product }\end{array}$ & 46,7 & 53,3 & \\
\hline $\begin{array}{l}\text { The recommendation system displays the products that } \\
\text { matched to reseller preference }\end{array}$ & 53,3 & 46,7 & \\
\hline Distributors & & & \\
\hline The system helps distributors to complete transactions & 33.3 & 66.7 & \\
\hline The system helps distributors process stock updates & 100 & & \\
\hline $\begin{array}{l}\text { The system recommendation helps distributors to } \\
\text { understand the reseller's needs by providing their preferred } \\
\text { product? }\end{array}$ & 33.3 & 66.7 & \\
\hline
\end{tabular}

\section{CONCLUSION}

The architectural design developed focuses on SMEs because it is at this business scale that is more affected during this pandemic. In addition, because so far, there has been no PRM system that focuses on SMEs, even though relationships are essential in a business of any scale. The application form of this design is an e-marketplace that implements a recommendation system to assist distributors in serving their resellers. The e-marketplace was chosen so that many small and medium-sized businesses can directly use this one system in need. Through the results of the trials carried out, it can also be seen that distributors and resellers feel helped by the design of this e-marketplace system. On average more than $50 \%$ strongly agree or agree that the system can help existing business processes.

Further research is still needed to see the impact of the broader application of this architectural design. Trials with more distributors and suppliers in different areas can be a means to see the influence of demographics on the architectural designs made.

\section{REFERENCES}

Agariya, A. K. and Singh, D. (2011) 'What Really Defines Relationship Marketing? A Review of Definitions and General and Sector-Specific Defining Constructs', Journal of Relationship Marketing, 10(4), pp. 203-237. doi: 10.1080/15332667.2011.624905.

Agarwal, A. and Singh, D. (2014) 'Journal of Internet Banking and Commerce Partner 
Dhiani, T.A., et al., Partner Relationship Management Architecture Design For SME During Pandemic Era, KELUWIH: Jurnal Sains dan Teknologi, Vol.2(2), 96-102, Agustus 2021.

https://doi.org/10.24123/saintek.v2i2.4567

Relationship Management (PRM) Index: An Innovative Approach For Enhancing Channel Partner Relationships', Journal of Internet Banking and Commerce, 19(1), pp. 1-13. Available at: http://www.arraydev.com/commerce/jibc/.

Agarwal, A., Singh, D. and Agariya, A. K. (2017) 'What Really Leads to Partner Relationship Management? A Review of Literature', Journal of Relationship Marketing. Taylor \& Francis, 16(4), pp. 245-285. doi: 10.1080/15332667.2017.1349557.

Barac, D. et al. (2017) 'Fostering partner relationship management in B2B ecosystems of electronic media', Journal of Business and Industrial Marketing, 32(8), pp. 1203-1216. doi: 10.1108/JBIM-02-2016-0025.

Barnes, S. J. (2020) 'Information management research and practice in the post-COVID-19 world', International Journal of Information Management. Elsevier, 55(June), p. 102175. doi: 10.1016/j.ijinfomgt.2020.102175.

Bermes, A. (2021) 'Information overload and fake news sharing: A transactional stress perspective exploring the mitigating role of consumers' resilience during COVID-19', Journal of Retailing and Consumer Services. Elsevier Ltd, 61(April), p. 102555. doi: 10.1016/j.jretconser.2021.102555.

vom Brocke, J., Hevner, A. and Maedche, A. (2020) 'Introduction to Design Science Research', (September), pp. 1-13. doi: 10.1007/978-3-030-46781-4_1.

Ernawati, E. and Hamid, N. (2021) 'Effects of environmental characteristics and business partner relationships on improving innovation performance through the mediation of knowledge management practices', VINE Journal of Information and Knowledge Management Systems, 51(1), pp. 139-162. doi: 10.1108/VJIKMS-09-2019-0137.

Fedotova, I., Shynkarenko, V. and Kryvoruchko, O. (2018) 'Development of the viable system model of partner relationship management of the company', International Journal of Engineering and Technology(UAE), 7(4.3 Special Issue 3), pp. 445-450. doi: 10.14419/ijet.v7i4.3.19913.

Fernandes, N. (2020) 'Economic effects of coronavirus outbreak ( COVID-19) on the world economy Nuno Fernandes Full Professor of Finance IESE Business School Spain', SSRN Electronic Journal, ISSN 1556-5068, Elsevier BV, pp. 0-29.

Gerwe, O. (2021) 'The Covid-19 pandemic and the accommodation sharing sector: Effects and prospects for recovery', Technological Forecasting and Social Change. Elsevier Inc., 167(March), p. 120733. doi: 10.1016/j.techfore.2021.120733.

Griffin, D. and Denholm, J. (2020) This isn't the first global pandemic, and it won't be the last. Here's what we've learned from 4 others throughout history, The Conversation. Available at: https://theconversation.com/this-isnt-the-first-global-pandemic-and-it-wont-be-thelast-heres-what-weve-learned-from-4-others-throughout-history-136231.

Gruenberg, B. D. A. et al. (2006) 'F Actors I Nfluencing L Ength of', 15(5), pp. 195-202.

Gupta, S., Väätänen, J. and Khaneja, S. (2016) 'Value added reseller or value at risk: The dark side of relationships with VARs', Industrial Marketing Management. Elsevier B.V., 55, pp. 110-118. doi: 10.1016/j.indmarman.2016.02.017.

Jiang, T. Q. and Lu, W. (2013) 'Improved slope one algorithm based on time weight', Applied Mechanics and Materials, 347-350(Iccsee), pp. 2365-2368. doi: 10.4028/www.scientific.net/AMM.347-350.2365.

Kedah, Z. Bin et al. (no date) 'Developing Web-Based Partner Relationship Management : An Exploratory Study of the Application of Web-Based Solutions by ICT Companies in Malaysia , Ireland and the United Kingdom', 51(1), pp. 67-87.

Leverin, A. and Liljander, V. (2004) 'Journal of Business \& Industrial Marketing', Journal of Business \& Industrial Marketing Management Decision International Journal of Bank Marketing Iss Journal of Product \&amp Brand Management, 19(11), pp. 5-14. Available at: http://dx.doi.org/10.1108/08858620410523981\%5Cnhttp://dx.doi.org/10.1108/002517 49610113613\%5Cnhttp://dx.doi.org/10.1108/02652320610671333\%5Cnhttp://dx.doi.or g/10.1108/10610421111108067\%5Cnwww.emeraldinsight.com/researchregister\%5Cnw 
Dhiani, T.A., et al., Partner Relationship Management Architecture Design For SME During Pandemic Era, KELUWIH: Jurnal Sains dan Teknologi, Vol.2(2), 96-102, Agustus 2021.

https://doi.org/10.24123/saintek.v2i2.4567

ww.emeraldinsight.com/0.

Li, P. et al. (2021) 'Retailer's vertical integration strategies under different business modes', European Journal of Operational Research. Elsevier B.V., 294(3), pp. 965-975. doi: 10.1016/j.ejor.2020.07.054.

Lim, C., Baba, K. and lijima, J. (2019) 'Developing a capability maturity model for smart tourism', Proceedings of the 23rd Pacific Asia Conference on Information Systems: Secure ICT Platform for the 4th Industrial Revolution, PACIS 2019, pp. 1-6.

Nayati Utami, H. et al. (2019) 'The interests of small- and medium-sized enterprises (SMEs) actor in using mobile commerce in effort to expand business network', Journal of Science and Technology Policy Management, 10(3), pp. 493-508. doi: 10.1108/JSTPM08-2018-0081.

Oliver Richard L. (1980) 'A Cognitive Model of the Antecedents and Consequences of Satisfaction Decisions', Journal of Marketing Research, 17(4)(November), pp. 460-469.

Sa Vinhas, A. and Gibbs, R. (2012) 'Competitive channel relationship management: When resellers establish competing manufacturer relationships', Marketing Letters, 23(3), pp. 645-659. doi: 10.1007/s11002-012-9168-3.

Sari, S. and Sary, A. P. (2017) 'Sistem Rekomendasi Personal Pada Toko Buku Online Menggunakan Pendekatan Collaborative Filtering Dan Algoritma Slope One', Seminar Nasional Teknologi Informasi san Multimedia, pp. 13-18.

Stokes, D. and Lomax, W. (2002) 'Taking control of word of mouth marketing: The case of an entrepreneurial hotelier', Journal of Small Business and Enterprise Development, 9(4), pp. 349-357. doi: 10.1108/14626000210450531.

Storey, C. and Kocabasoglu-Hillmer, C. (2013) 'Making partner relationship management systems work: The role of partnership governance mechanisms', Industrial Marketing Management. Elsevier Inc., 42(6), pp. 862-871. doi: 10.1016/j.indmarman.2013.05.019.

Tsay, A. A. and Agrawal, N. (2004) 'Channel conflict and coordination in the E-commerce age', Production and Operations Management, 13(1), pp. 93-110. doi: 10.1111/j.19375956.2004.tb00147.x.

Vos, F. G. S. et al. (2021) 'Mediating the impact of power on supplier satisfaction: Do buyer status and relational conflict matter?', International Journal of Production Economics. Elsevier B.V., 239(January), p. 108168. doi: 10.1016/j.ijpe.2021.108168.

Wu, M. Y. et al. (2011) 'Supply chain performance improvement through partner relationship management in the high tech industry', International Journal of Management Science and Engineering Management, 6(3), pp. 210-218. doi: 10.1080/17509653.2011.10671165. 